\title{
Isolation, Purification and Quantification of Enterocin from Enterococcus Species and Potential antibacterial activity
}

\author{
Aratrika Razdan ${ }^{* 1}$, Rakesh Kumar², Ajit Kumar³ \\ *1 Department of Biotechnology, Kanoria PG Mahila Mahavidyalaya Jaipur, Rajasthan \\ 2 Department Biochemistry, Mewar University Chittorgarh, Rajasthan \\ ${ }^{3}$ Seminal Applied Sciences Pvt. Ltd. Jaipur, Rajasthan
}

\begin{abstract}
Enterococcus is a large genus of lactic acid bacteria of the phylum Firmicutes. Enterococci are Gram-positive cocci that often occur in pairs (Diplococci) or short chains. The purpose of this study was to determine the antimicrobial activity and occurrence of Enterocin in Enterococcus species isolated from different clinical samples. In this study, isolate Enterococcus in nutrient agar media. Perform biochemical testing and gram staining for identification of Enterococcus and sub culture in BHI (Brain Heart Infusion) and LAPTg broth. Enterocin was isolated from broth by different spectral techniques and used as an antibiotic against selective bacteria (Staphylococcus aureus, Bacillus, Escherichia coli and Streptomyces).
\end{abstract}

Keywords: - Clinical Samples; Enterococcus Spp.; Enterocin; Catalase; SDS-PAGE.

Article Info: Received 17 July 2019; Review Completed 21 August 2019; Accepted 25 August 2019; Available online 30 Aug 2019

Cite this article as:

Razdan A, Kumar R, Kumar A, Isolation, Purification and Quantification of Enterocin from Enterococcus Species and Potential antibacterial activity, Journal of Drug Delivery and Therapeutics. 2019; 9(4-A):197-202

http://dx.doi.org/10.22270/jddt.v9i4-A.3452

a

Kumar Rakesh, Department Biochemistry, Mewar University Chittorgarh, Rajasthan

\section{INTRODUCTION:}

In recent years bacterial antibiotic resistance has been considered a problem due to the extensive use of classical antibiotics in treatment of human and animal diseases (Roy, 1997; Lipsitch et al, 2000; Yoneyama and Katsumata, 2006). As a consequence, multiple resistant strains appeared and spread causing difficulties and the restricted use of antibiotics as growth promoters. So, the continuous development of new classes of antimicrobial agents has become of increasing importance for medicine (Kumar and Schweiser, 2005; Fisher et al, 2005).

Bacteriocins/ Enterocin are proteins or complex proteins biologically active with antimicrobial action against other bacterial species. They are produced by bacteria and are normally not termed antibiotics in order to avoid confusion and concern with therapeutic antibiotics, which can potentially illicit allergic reactions in humans and other medical problems (Deraz et al, 2005).

The genus Enterococcus is now comprised of more than 20 species of which Enterococcus faecalis and Enterococcus faecium are the most common species and are readily found in the faeces of mammals. Faecal enterococci have been classified as "faecal indicator" bacteria in the same way as faecal coliforms, i.e., as an indicator of unsanitary manufacture or processing of foods. Because of their association with animals and faecal distribution, enterococci are found worldwide in a large variety of fresh and prepared foods, vegetables, hard cheeses, meats and prepared meat products (Devriese and Pot, 1995; Pesavento, et al., 2014 and Gomes, et al., 2008).

A common technique used to differentiate two large groups of bacteria based on their different cell wall constituents. The Gram stain procedure distinguishes between Grampositive and Gram-negative groups by colouring these cells red and violet. Alternatively, Gram negative bacteria stain red, which is attributed to a thinner peptidoglycan wall, which does not retain the crystal violet during the decolouring process (Bhattacharyya S, et al., (2015).

Sodium Dodecyl Sulfate-polyacrylamide Gel Electrophoresis is an analytical method in biochemistry for the separation of charged molecules in mixtures by their molecular masses in an electric field. It uses Sodium Dodecyl Sulfate (SDS-PAGE) 
molecules to help identify and isolate protein molecules (Laemmli U K, (1970).

Bacterial isolates were used in this study for antibacterial activity. The well diffusion plate method (Jagessar R C, et al., 2008) was used for antimicrobial activity. Anti bacterial activity presented drug susceptibility against bacterial isolate.

\section{MATERIAL AND METHODS:}

\section{Sample collection}

Clinical samples of Urine, Pus, Sputum, Pleural Fluid, Cerebrospinal Fluid and Blood were collected from Hospital and Medical Collages, Haryana.

\section{MEDIA}

Nutrient Agar is a general, purpose medium supporting growth of a wide range of non-fastidious organisms. It typically contains (mass/volume): $0.5 \%$ Peptone, $0.3 \%$ beef / yeast extract, 1.5\% Agar agar, $0.5 \%$ Sodium Chloride and distilled water, $\mathrm{pH}$ adjusted to neutral (6.8) (Lapage $\mathrm{S}$ et al., (1970); MacFaddin J F, (2000). It is one of the most frequently used as non-selective media useful in routine cultivation of microorganisms (American Public Health Association, (1978); Salfinger and Tortorello, (2015).

\section{BROTH}

- $\quad$ LAPTg Broth composed of Peptone - 15g/l, Tryptone $10 \mathrm{~g} / \mathrm{l}$, Yeast Extract - $10 \mathrm{~g} / \mathrm{l}$, Tween $80-1 \mathrm{ml} / \mathrm{l}$ and Glucose - 10g/l (Raibaud et al., 1973).

- BHI (Brain Heart Infusion) Broth is a general purpose medium used for the isolation, cultivation, and maintenance of a variety of fastidious and non fastidious microorganisms. BHI broth composed of Calf Brain infusion form - 200g/l, Beef Heart infusion 250g/l, Proteose - 10g/l, NaCl - 5g/l, Dextrose - 2g/l, Di sodium phosphate - 2.5g/l (MacFaddin JF, (1985).

\section{SDS PAGE STOCK SOLUTION}

Resolving Gel: Acryl/Bisacryl, LGB, SDS 10\%, APS 20\% TEMED, Stacking Gel: Acryl/Bisacryl, UGB, SDS 10\%, APS 20\% TEMED, Electrode Buffer: Tris base $1.5 \mathrm{~g}, 7.2 \mathrm{~g}$ glycine, $0.5 \mathrm{~g}$ SDS in $500 \mathrm{ml}$ distilled water, Protein Sample Buffer: $62.5 \mathrm{Mm}$ Tris HCL $0.76 \mathrm{gm}(6.8 \mathrm{pH}), 2.0 \mathrm{ml}$ glycerol, $2 \mathrm{ml}$ SDS, $0.5 \mathrm{ml} \beta$-mercapto ethanol, $0.01 \%$ bromophenol blue $0.001 \mathrm{~g}$ bromophenol blue dissolve in $5 \mathrm{ml}$ distilled water), $5 \mathrm{ml}$ distilled water, Protein Marker, Staining Solution: $630 \mathrm{ml}$ distilled water, $300 \mathrm{ml}$ methanol, $70 \mathrm{ml}$ glacial acetic acid, $800 \mathrm{mg}$ comassie brilliant blue G 250 and De-staining Solution: $30 \mathrm{ml}$ distilled water, $300 \mathrm{ml}$ methanol, $70 \mathrm{ml}$ glacial acetic acid (Laemmli U K, (1970).

\section{METHODS:}

\section{Culture Media}

A culture media is a special medium used in microbiological laboratories to grow different kinds of microorganisms. A Culture medium is composed of different nutrients that are essential for microbial growth. A culture may be solid or liquid. The solid culture media is composed of a brown jelly like substance known as agar. Different nutrients and chemicals are added to it to allow the growth of different microorganisms. This is composed of all the basic nutrients required for a microbial growth used to preserve a specific type of microorganism, for a long period of time (Collins $\mathrm{C} \mathrm{H}$, (1967); Denyer S P, et al., (2004); Stainer R Y, et al., (1987) \& Sandle T, (2011).
Nutrient agar mixed with distilled water according to requirement $(28.0 \mathrm{~g} / \mathrm{L})$ and boiled for approximately one minute to ensure they are mixed and then sterilized by autoclaving, typically at $121^{\circ} \mathrm{C}\left(250^{\circ} \mathrm{F}\right)$ for 15 minutes. Then they are cooled to around $45^{\circ} \mathrm{C}-50^{\circ} \mathrm{C}\left(122^{\circ} \mathrm{F}\right)$ and poured into Petri dishes which are covered immediately. Once the dishes hold solidified agar, they are stored upside down and are often refrigerated until use (American Public Health Association, (1917).

\section{Inoculation:}

Nutrient agar, culture media must be checked visually before use for contamination, significant physical imperfections and preparation date, if contaminated that should be discarded. Inoculation loops can be 'wire or disposable loops. Disposable loops were initially used in safety cabinets to avoid sterilisation with Bunsen burners but now their use is common practice to comply with the health and safety regulations. Disposable loops are also desirable for quantitative purposes. Wire loops are rarely used in clinical microbiology laboratories in the UK to reduce the risk of infection from aerosols of pathogenic organisms and, cross contamination from improper sterilisation of the wire loops. Clinical samples are streaked on the nutrient agar media by quadrant method; the streaked plates are then incubated at $37^{\circ} \mathrm{C}$ for 24 hours and observed (The Australian Society for Microbiology, (2012).

\section{IDENTIFICATION:}

Isolated microbes identified by the process of microscopy and biochemical testing i.e. Gram staining and Catalase test respectively.

\section{Gram staining procedure}

Take a clean and dry glass slide and make a smear with the isolated microbes. Leave it for air dried, apply crystal violet on the smear and leave it for 60 to 90 seconds, slowly wash the smear with distilled or running tap water and apply Gram's iodine, leave it for 60 seconds, again, slowly wash the slide, now, cover the smear with ethanol for 10 seconds and wash it, apply safranin and leave it for 45 seconds, wash the slide and cover the smear with methylene blue, leave it for 30 seconds, wash and dry it (Bhattacharyya S, et al., (2015); Beveridge TJ, (2001) \& Coico R, (2005).

\section{Catalase}

The enzyme catalase mediates the breakdown of hydrogen peroxide into oxygen and water. The presence of the enzyme in a bacterial isolate is evident when a small inoculum is introduced into hydrogen peroxide (Wheelis M, (2008), and the rapid elaboration of oxygen bubbles occur. The lack of catalase is evident by a lack of or weak bubble production. The culture should not be more than 24 hours old. The bacteria thereby protect themselves from the lethal effect of hydrogen peroxide which is accumulated as an end product of aerobic carbohydrate metabolism (MacFaddin J F, (2000) \& Clarke H and Cowan ST, (1952). One of the most popular methods in clinical bacteriology is the slide or drop catalase method, because it requires a small amount of organism and relies on a relatively uncomplicated technique. This protocol delineates the procedure for the qualitative slide and tube catalase methods, which are primarily used for the differentiation of staphylococci and streptococci.

\section{Procedure:}

Use a loop or sterile wooden stick to transfer a small amount of colony from growth in the surface of a clean and dry glass slide. Place a drop of $3 \%$ hydrogen peroxide $\left(\mathrm{H}_{2} \mathrm{O}_{2}\right)$ on the 
glass slide and observe the evaluation of oxygen bubbles (Reiner K, (2010).

\section{ISOLATION OF ENTEROCIN}

The bacterial isolates inoculated in LAPTg and BHI broth were incubated at $30^{\circ} \mathrm{C}$ for 2 to 3 days or till proper growth. After proper growth of the strain it was centrifuged at $15000 \mathrm{rpm}$ for 20 minutes at $4^{\circ} \mathrm{C}$. Then the supernatant was collected and $\mathrm{pH}$ maintained $(\mathrm{pH} 7.0)$. Supernatant was passed through the membrane filter $(0.22 \mu \mathrm{m})$, after that 40\% Ammonium Sulfate was added up the saturation with constant stirring at room temperature. It was again centrifuged at $15000 \mathrm{rpm}$ for 20 minutes at $4^{\circ} \mathrm{C}$. Supernatant was discarded and pallet was dissolved in $0.1 \mathrm{M}$ Sodium Phosphate buffer and stored at $2^{\circ} \mathrm{C}$ to $8^{\circ} \mathrm{C}$ temperature for 2 days. Purification was done by dialyzing the sample in semi permeable membrane and placing it into $0.1 \mathrm{M}$ Sodium Phosphate buffer between $4^{\circ} \mathrm{C}$ to $10^{\circ} \mathrm{C}$ temperature for 3 to 4 days (Ahmed S, et al., (2004).

SDS PAGE (Sodium Dodecyl Sulfate-polyacrylamide) Gel Electrophoresis

Fix the glass plate sandwich using two clean $1 \mathrm{~mm}$ spacers. Then lock the sandwich to the casting stand and seal edges with agar. After that by using the Pasteur pipette, resolving gel was poured to the sandwich along the edges of the spacers. Then the gel was left at room temperature for 15-20 minutes for polymerisation. After polymerisation of resolving gel, stacking gel was poured into the centre of the sandwich. Then the Teflon comb was immediately inserted in the stacking gel solution. After that again the stacking gel was left for 30-40 minutes at room temperature for polymerisation. After polymerisation of stacking gel, comb was removed carefully. Gel plate was assembled on the electrophoretic apparatus. Electrode buffer was added to the top and bottom reservoirs. Samples were loaded $(40 \mu \mathrm{l}$ enterocin $+40 \mu$ l protein sample buffer) per well with

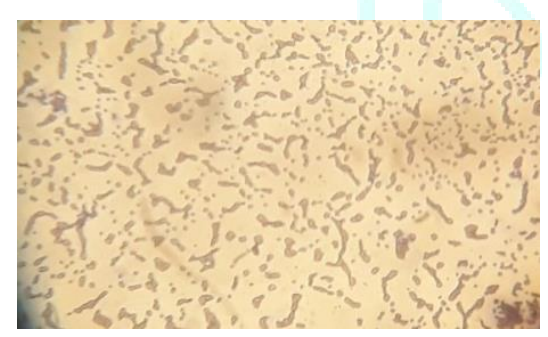

Gram stain smear Pus Culture

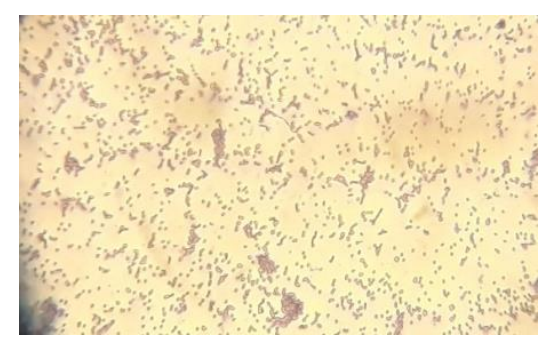

Gram stain smear Sputum Culture micropipette. The gel was run at $50 \mathrm{~V}$ till the dye migrated to the bottom of the resolving gel (Laemmli U K, (1970).

\section{Staining and De-staining}

After completion of electrophoresis, proteins were fixed by soaking the gel in 20 percent TCA for 10 minutes. The gel was washed with 7 percent acetic acid and immerged in staining solution containing $360 \mathrm{ml}$ distilled water, $300 \mathrm{ml}$ of methanol, $70 \mathrm{ml}$ glacial acetic acid and $800 \mathrm{mg}$ coomassie blue (G-50) and finally made the volume equal to 1 litre. After 1-1.30 hours the staining solution was poured off and the excess dye was eluted with 3-4 change of the de-staining solution. For further de-staining gel was agitated with 7 percent acetic acid on shaking rocker continuously until the background was clear properly (Laemmli U K, (1970).

\section{ANTIBACTERIAL ACTIVITY}

Agar well-diffusion method was followed to determine the antibacterial activity. Nutrient agar (NA) plates were swabbed (sterile cotton swabs) with 8 hour old - broth culture of respective bacterial isolates. Wells $(10 \mathrm{~mm}$ diameter and about $2 \mathrm{~cm}$ a part) were made in each of these plates using sterile cork borer. Stock solution of (of what?) was prepared at a concentration of $1 \mathrm{mg} / \mathrm{ml}$. Enterocin sensitivity against different bacterial isolates in the concentration of $20 \mu \mathrm{l}, 30 \mu \mathrm{l}, 40 \mu \mathrm{l}$ and $50 \mu \mathrm{l}$ and another concentration $60 \mu \mathrm{l}, 80 \mu \mathrm{l}, 100 \mu \mathrm{l}$ and $120 \mu \mathrm{l}$ into the wells and allowed to diffuse at room temperature for $2 \mathrm{hrs}$. The plates were incubated at $37^{\circ} \mathrm{C}$ for $18-24 \mathrm{~h}$ for bacterial pathogens (Sen and Batra, (2012).

\section{RESULT \& DISCUSSION}

\section{Gram Staining}

Gram-negative bacteria seen in brick red colour and grampositive bacteria appear in violet colour. Enterococcus was observed under the microscope and belongs to grampositive cocci occurring in pairs (Diplococci) or short chains shown in following figures.

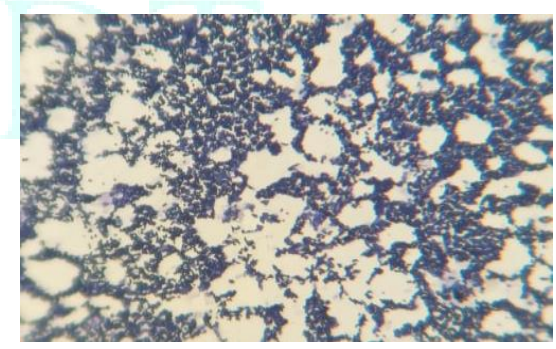

Gram stain smear Pleural Fluid Culture

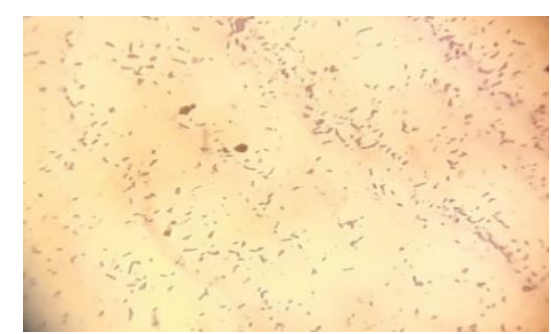

Gram stain smear CSF Fluid Culture 


\section{Catalase}

The morphologically similar enterococcus or streptococcus is catalase negative.

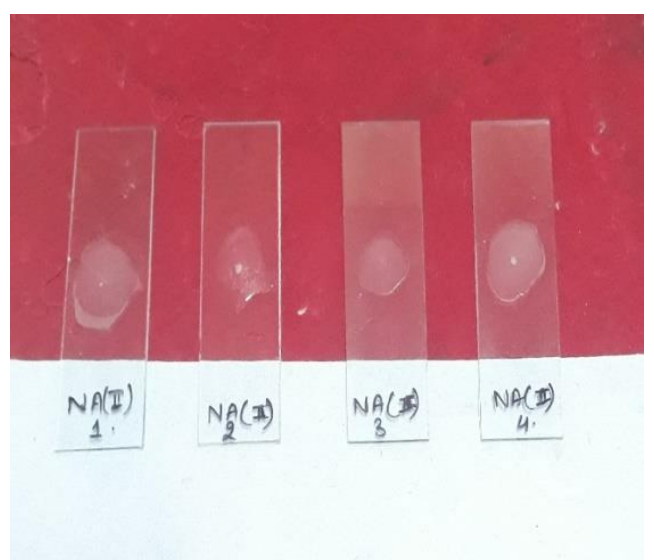

Sample: 1 - Pus; 2 - Pleural Fluid; 3 - Sputum; 4 - CSF.

Positive: - Copious bubbles produced, active bubbling

For example: - Staphylococci, Micrococci, Pseudomonas, Aspergillus and Mycobacterium tuberculosis etc.

Negative: - No or very few bubbles produced.

For example: - Streptococcus and Enterococcus species.

\section{Isolation of Enterocin}

Enterocin placed for dialysis into $0.1 \mathrm{M}$ Sodium Phosphate buffer between $4{ }^{\circ} \mathrm{C}$ to $10{ }^{\circ} \mathrm{C}$ temperature for 3 to 4 days.

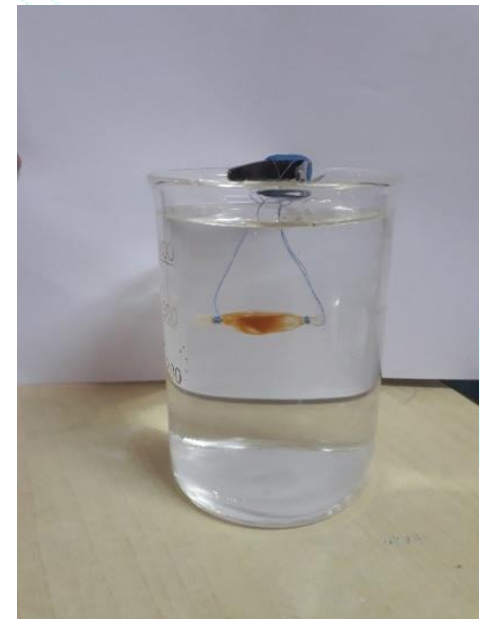

Before dialysis

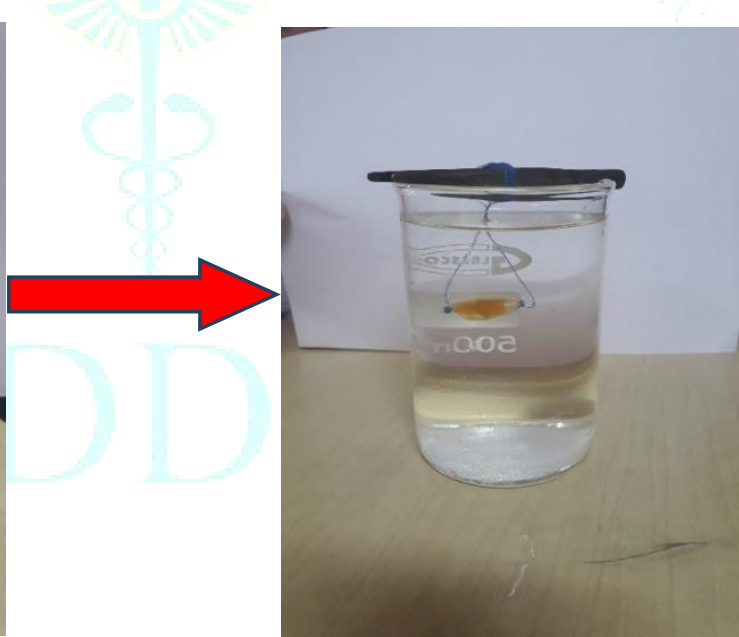

after three days dialysis

\section{SDS-PAGE}

SDS-PAGE was performed according to Laemmli, (1970) using 15\% polyacrylamide gel, run at 100V. Protein standard of medium range 16-209kDa was used as molecular weight marker and visualised by staining with Coomassie brilliant blue G-250. The molecular weight of the sample was observed to be $16 \mathrm{kDa}$ i.e. Enterocin. 


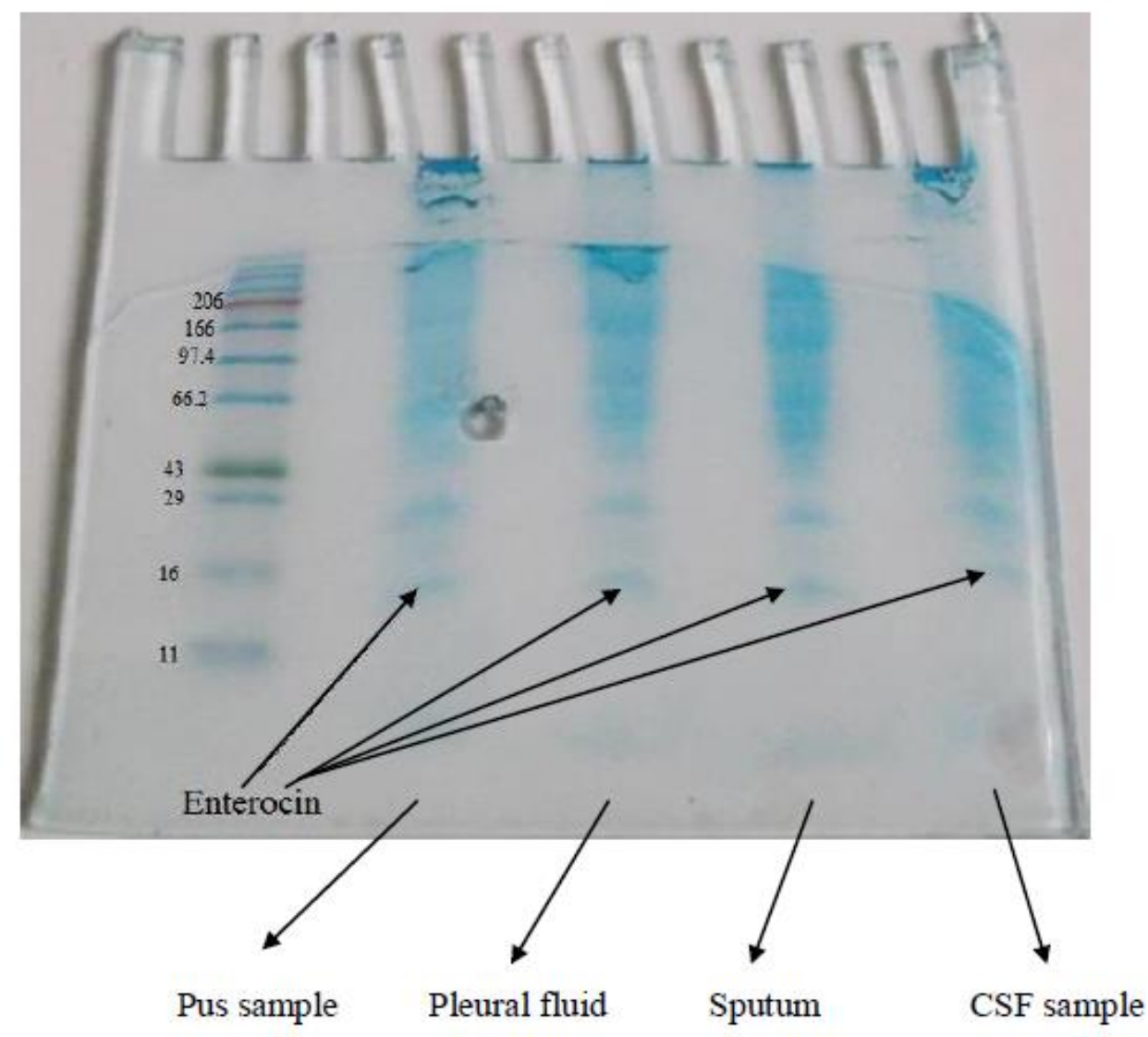

\section{Antimicrobial activity}

Enterocin sensitivity/ susceptibility against different bacterial isolates in the concentration of $1 \mathrm{mg} / \mathrm{ml}$ and Enterocin load two different lots one was $20 \mu \mathrm{l}, 30 \mu \mathrm{l}, 40 \mu \mathrm{l}, 50 \mu \mathrm{l}$ and second was $60 \mu \mathrm{l}, 80 \mu \mathrm{l}, 100 \mu \mathrm{l}, 120 \mu \mathrm{l}$ shown in following table.

\begin{tabular}{|c|c|c|c|c|c|}
\hline \multirow{2}{*}{ Sr. No. } & \multicolumn{5}{|c|}{ Enterocin extract Concentration in $1 \mathrm{mg} / \mathrm{ml}$} \\
\hline & Standard & $20 \mu \mathrm{L}$ & $30 \mu \mathrm{L}$ & $40 \mu \mathrm{L}$ & $50 \mu \mathrm{L}$ \\
\hline E. coli & $38 \mathrm{~mm}$ & $10 \mathrm{~mm}$ & $10 \mathrm{~mm}$ & $12 \mathrm{~mm}$ & $13 \mathrm{~mm}$ \\
\hline Bacillus & $30 \mathrm{~mm}$ & $<6 \mathrm{~mm}$ & $<6 \mathrm{~mm}$ & $<6 \mathrm{~mm}$ & $<6 \mathrm{~mm}$ \\
\hline Streptomyces & $43 \mathrm{~mm}$ & $9 \mathrm{~mm}$ & $11 \mathrm{~mm}$ & $12 \mathrm{~mm}$ & $14 \mathrm{~mm}$ \\
\hline S. aureus & $42 \mathrm{~mm}$ & $13 \mathrm{~mm}$ & $15 \mathrm{~mm}$ & $17 \mathrm{~mm}$ & $20 \mathrm{~mm}$ \\
\hline
\end{tabular}

Note: E. coli - Escherichia coli; S. aureus - Staphylococcus aureus; Standard - Ciprofloxacin.

\begin{tabular}{|c|c|c|c|c|c|}
\hline \multirow{2}{*}{ Sr. No. } & \multicolumn{5}{|c|}{ Sample Enterocin Concentration in $1 \mathrm{mg} / \mathrm{ml}$} \\
\hline & Standard & $60 \mu \mathrm{L}$ & $80 \mu \mathrm{L}$ & $100 \mu \mathrm{L}$ & $120 \mu \mathrm{L}$ \\
\hline E. coli & $38 \mathrm{~mm}$ & $12 \mathrm{~mm}$ & $13 \mathrm{~mm}$ & $14 \mathrm{~mm}$ & $15 \mathrm{~mm}$ \\
\hline Bacillus & $30 \mathrm{~mm}$ & $<6 \mathrm{~mm}$ & $<6 \mathrm{~mm}$ & $<6 \mathrm{~mm}$ & $<6 \mathrm{~mm}$ \\
\hline Streptomyces & $43 \mathrm{~mm}$ & $12 \mathrm{~mm}$ & $16 \mathrm{~mm}$ & $18 \mathrm{~mm}$ & $19 \mathrm{~mm}$ \\
\hline S. aureus & $42 \mathrm{~mm}$ & $12 \mathrm{~mm}$ & $14 \mathrm{~mm}$ & $18 \mathrm{~mm}$ & $20 \mathrm{~mm}$ \\
\hline
\end{tabular}

Note: - E. coli - Escherichia coli; S. aureus - Staphylococcus aureus; Standard - Ciprofloxacin. 


\section{CONCLUSION}

The present study indicates the importance of Enterocin extract from Enterococcus bacteria. Enterocin is a type of protein, the molecular weight of the sample was observed to be $16 \mathrm{kDa}$. Protein is a most valuable energy source for growth cell and tissue repair and might be used in the treatment of human diseases.

\section{REFERENCES}

1. Ahmed S, Alfred I and Rasool S A, Isolation and biochemical characterization of Enterocin Esf100 Produced by Enterococcus faecalis Esf100 Isolated From A Patient Suffering From Urinary Tract Infection Pakistan Journal of Botany, 2004; 36(1), 145-158.

2. American Public Health Association, Standard methods of water analysis, 3rd ed. American Public Health Association, New York, N.Y, 1917.

3. American Public Health Association, Standard Methods for the Examination of Dairy Products, 14th Ed., Washington D.C. 1978.

4. Beveridge TJ, Use of the gram stain in microbiology, Biotech Histochem, 2001; 76, 111-18.

5. Bhattacharyya S, Prasad A, Sarfraz A, Jaiswal NK and Kumar R, Evaluation of a new method for Gram staining of bacteria, Medical Science, 2015; 18(73), 16-17, ISSN 2321 - 7359 EISSN 2321 - 7367.

6. Clarke $\mathrm{H}$ and Cowan ST, Biochemical methods for bacteriology Journal General Microbiology, 1952; 6:187-197.

7. Coico R, Gram Staining, Current Protocol Microbiology, Appendix 3: Appendix 3C. 2005; doi: 10.1002/9780471729259.mca03cs00.

8. Collins C H, Microbiological Methods, London: Butterworths, 1967.

9. Denyer S P, Hodhes N A and Gorman S P, Hugo and Russell's Pharmaceutical Microbiology, 7th Edition, London: Blackwell Publishing, 2004; pp14-15.

10. Deraz S. F., Karlsson E. N., Hedstrom M., Andersson M. M and Mattiasson B. (2005); Purification and characterisation of acidocin D20079, a bacteriocin produced by Lactobacillus acidophilus DSM 20079. J. Biotechnol., 117, 343-354.

11. Devriese LA and Pot B, The genus Enterococcus. In: Wood BJB, Holzapfel WH (eds) The lactic acid bacteria. The genera of lactic acid bacteria, vol 2. Blackie, London, 1995; pp 327-367.

12. Fisher J. F., Meroueh S. $\mathrm{O}$ and Mobashery S. Bacterial resistance to beta-lactam antibiotics: compelling opportunism, compelling opportunity. Chem. Rev., 2005; 105, 395-424.

13. Gomes B C, Esteves C T, Palazzo I C V, Darini A L C, Felis G E, Sechi L A, Franco B D G M and Martinis de E C P, Prevalence and characterization of Enterococcus spp. Isolated from brazilian foods. Food Microbiology, 2008; 25, 668-675.

14. Jagessar R C, Marsa A and Gomesb G, Selective antimicrobial properties of Phyllanthus acidus leaf extract against Candida albicans, Escherichia coli and Staphylococcus aureus using stokes disc diffusion, well diffusion, streak plate and a dilution method. Nat. \& Sci. 2008; 6: 24-38.

15. Kumar A and Schweiser H. P, Bacterial resistance to antibiotics: active efflux and reduced uptake. Adv. Drug Deliery Reviwe 57, 2005; 1486-1513.
16. Laemmli $\mathrm{U} \mathrm{K}$, Cleavage of structural proteins during the assembly of the head of bacteriophage T4. Nature, 1970; 227(5259): 680-685.

17. Lapage S, Shelton J and Mitchell T, Methods in Microbiology', Norris J. and Ribbons D., (Eds.), Vol. 3A, Academic Press, London, 1970.

18. Lipsitch M., Bergstrom C. T. and Levin B. R., the epidemiology of antibiotic resistance in hospitals: paradoxes and prescriptions. Proc. Natl. Acad. Sci. USA, 2000; 97, 1938-1943.

19. MacFaddin J F, Biochemical tests for identification of medical bacteria, 3rd ed. Lippincott Williams \& Wilkins, Philadelphia PA, 2000.

20. MacFaddin J F, Biochemical Tests for Identification of Medical Bacteria, 3rd Ed., Lippincott, Williams and Wilkins, Baltimore, 2000.

21. MacFaddin JF, Media for isolation cultivation-maintenance of medical bacteria, Vol. I. Baltimore: Williams \& Wilkins, 1985.

22. Manolopoulou E., Sarantinopoulos P., Zoidou E., Aktypis A., Moschopoulou E, Kandarakis GI., and Anifantakis EM, Evolution of microbial populations during traditional Feta cheese manufacture and ripening International Journal Food Microbiology, 2003; 82: 153-161.

23. Pesavento G, Calonico C, Ducci B, Magnanini A and Nostro L A, Prevalence and antibiotic resistance of Enterococcus spp. isolated from retail cheese, ready-to-eat salads, ham, and raw meat. Food Microbiological, 2014; 41, 1-7.

24. Raibaud P, Galpin J V, Ducluzeau R, Mocquot G \& Oliver G, Le genre Lactobacillus dans le tube digestif du rat. II. Caracte'res de souches heterofermentaires isole'es de rats "Holo" et "Gnotoxe'niques". Ann Inst Pasteur Microbiol, 1973; 124A, 2223-2235 (in French).

25. Reiner Karen, Catalase protocol, American Society for Microbiology, Bartlett Publishers, Inc., Sudbury, MA, 2010; 66.208.62.130.

26. Roy, P. H, Dissemination of antibiotic resistance. Med. Sci., 1997; 13, 927-933.

27. Salfinger Y and Tortorello M L, Compendium of Methods for the Microbiological Examination of Foods, 5th Ed., American Public Health Association, Washington D. C. 2015.

28. Sandle T, 'Selection of Microbiological Culture Media and Testing Regimes' in Saghee, M.R., Sandle, T. and Tidswell, E.C. (Eds.) (2011): Microbiology and Sterility Assurance in Pharmaceuticals and Medical Devices, New Delhi : Business Horizons, 2011; pp101-120.

29. Sen A and Batra A, Evaluation of Antimicrobial Activity of Different Solvent Extracts of Medicinal Plant: Melia Azedarach L. Int J Curr Pharm Res, 2012; ISSN- 0975-7066, Vol 4, Issue 2, 67-73.

30. Stainer $\mathrm{R} \mathrm{Y}$, Ingraham $\mathrm{J} \mathrm{L}$, Wheelis $\mathrm{M} \mathrm{L}$ and Painter $\mathrm{P} \mathrm{R}$. General Microbiology, 5 th Edition, Basingstoke: Macmillan, 1987; pp22-23.

31. The Australian Society for Microbiology, Guidelines for Assuring Quality of Medical Microbiological Culture Media: Australian Society for Microbiology, Inc, 2012; 1-32. A, V

32. Wheelis M, Principles of modern microbiology Jones Bartlett Publishers, Inc., Sudbury, MA. 2008.

33. Yogurtcu N.N and Tuncer. Antibiotic susceptibility patterns of Enterococcus strains isolated from Turkish Tulum cheese. Int J. Dairy Technol. 2013; 66(2): 236-242.

34. Yoneyama $\mathrm{H}$ and Katsumata $\mathrm{R}$, Antibiotic Resistance in Bacteria and Its Future for Novel Antibiotic Development Biosciences, Biotechnology and Biochemistry, 2006; 70, 10601075. 